\title{
Empowering a group of seniors in a rural community*
}

\author{
Potencializando um grupo de terceira idade de uma comunidade rural \\ Potenciando a un grupo de tercera edad de una comunidad rural
}

\begin{abstract}
Ana Rita Marinho Machado', Walterlânia Silva Santos², Flavia Aparecida Dias ${ }^{3}$, Darlene Mara dos Santos Tavares 4 Denize Bouttelet Munari ${ }^{5}$
\end{abstract}

\begin{abstract}
* Extracted from "Potencializando um grupo de idosos em uma comunidade rural com vistas à promoção da saúde: pesquisa convergente assistencial," Post-graduate Program in Health Sciences, Universidade Federal de Goiás, 2013.

${ }^{1}$ Associate Professor, Department of Nursing in Education and Community Health, Universidade Federal do Triângulo Mineiro, Uberaba, MG, Brasil.

${ }^{2}$ Associate Professor, Faculty of Ceilândia, Universidade de Brasília, Brasília, DF, Brasil.

${ }^{3}$ Doctoral Student, Post-graduate Program stricto sensu in Health Care, Universidade Federal do Triângulo Mineiro, Uberaba, MG, Brasil.
\end{abstract}

${ }^{4}$ Associate Professor, Department of Nursing in Education and Community Health, Universidade Federal do Triângulo Mineiro, Uberaba, MG, Brasil.

${ }^{5}$ Tenured Professor, Faculty of Nursing, Universidade Federal de Goiás, Goiás, GO, Brasil.

\section{ABSTRACT}

The present study describes the stages of empowerment of a group of seniors in a rural community in view of the convergent analysis. Study conducted with the proposal to change the praxis of 21 seniors and nine health professionals, with a view to their empowerment for health promotion, whose intervention suggested the incorporation of new group functioning. Data were collected during 22 meetings, and group interviews at the end of the intervention. The results show that despite the initial impact of the change, the group was able to welcome the new, enjoying the space to express anguish, share joys, build new knowledge, which led to the incorporation of changes reflected in the development of healthy habits and improves in interpersonal relationships. It is concluded that the convergent research consisted in strategy that changed the group life, boosting the actions of health promotion.

\section{DESCRIPTORS:}

Aged; Rural Population; Group Processes; Health Promotion; Community Health Nursing; Health of the Elderly.

\section{Correspondence Addressed to:} Ana Rita Marinho Machado Universidade Federal do Triângulo Mineiro, Centro de Graduação em Enfermagem. Praça Manoel Terra, 330 - Centro CEP 38015-050 - Uberaba, MG, Brasil E-mail: anarita@mednet.com.br 


\section{INTRODUCTION}

Currently, there are about 20.5 million people aged over 60 years in Brazil, representing approximately $10.8 \%$ of the population ${ }^{(1)}$. This contingent needs care in order to broaden the healthy period of life ${ }^{(2)}$.

A review study showed that there are barriers of access to health services for the elderly due to geographic, economic, social, demographic, cultural and functional barriers ${ }^{(3)}$.

In this sense, groups consisting of older people have been conducted towards empowerment strategies ${ }^{(2)}$, which can be conceptualized as a greater sense of control over one's life that people experience through belonging to distinct groups ${ }^{(3-4)}$. This is one of the structural concepts of health promotion and refers to the ability of human beings to live the different stages of life and deal with the limitations imposed by morbidities that may occur ${ }^{(4)}$.

In groups, empowerment is enhanced as people develop interactive actions with shared experiences ${ }^{(2.5)}$. Insertion into these groups has facilitated social engagement of the elderly, a determining factor in combating chronic diseases ${ }^{(6)}$.

Studies conducted in recent years have shown that group practices have been a strategy to promote health for the elderly ${ }^{(2,5,6-11)}$. But most of the research, particularly in Brazil, involves elderly groups in urban areas ${ }^{(2,5,7-11)}$. In general, investigations involving the health of elderly living in rural areas were restricted to describe the epidemiological profile of certain situations ${ }^{(12-15)}$. Thus, we identified a gap in the specialized literature related to the use of group activities as a strategy to promote the health of older people living in rural communities. These aspects motivated the development of this study aimed to describe the stages of the empowerment process of a group of seniors in a rural community.

\section{METHOD}

Convergent Care Research (CCR) ${ }^{(16)}$ whose foundation is to use the scope of practice involving the professionals who work in a given scenario in order to generate changes and improvements in care. In this sense, CCR allows the researcher to integrate the research and caring process, being inspired by new research paradigms including the naturalist, the constructivist and interpretive ${ }^{(17)}$.

In the case of this research, there was a proposal to change the practice of a group which was restricted to forró dance activities and playing bingo games, with an aim to empower health promotion and incorporating new group functions.

The study setting was a rural community in Minas Gerais. It was attended by members of a group of seniors, their coordinator and professionals of the Family Health Team (FHT). Inclusion criteria were: belonging to the group for at least one year and attending at least three meetings per month. For health professionals, the criterion was working in the FHT for at least six months and that in some way would be assisting in group activities. In the first meeting, participants were presented the objectives and method of research and then asked to sign the Informed Consent Statement.

The group intervention occurred in the Basic Health Unit (BHU) during weekly meetings with approximate duration of two hours. The intervention was driven by the principles of Kurt Lewin's group dynamics ${ }^{(18)}$, whose group intervention is based on the dynamics of small groups. This perspective has founded the CCR intervention process, with a view to focus on the group as a process, rather than on the individuals alone ${ }^{(18)}$.

The research was conducted between January/2011 and May/2012, a period in which 22 meetings were conducted and recorded while conducting the activity. The meetings were planned and executed in partnership with local coordination in order to integrate the participation of researchers and the local coordinator with the intention of empowering her to maintain the group's new strategy after the end of the research. There were also group interviews with the intention to formally evaluate the intervention conducted by an external researcher of the group.

Thus, the recorded testimonies of the intervention constituted the research materials of the investigation (a script was incorporated analyzing features related to social atmosphere of the group, the expression of ideas, feelings and possible interventions), the content of the assessment interviews from the researcher and the external evaluator with the members, with health team members and local coordinator of the group.

For participants of the elderly group, the central guiding question used was: "Have you noticed any change / difference in your life after this new way of conducting the group?" To facilitate dialogue, the participants were divided into three subgroups, with about six people in each.

The group interview with health professionals was conducted on a single day with the participation of eight members and guided by the following key question: Have you noticed a change in behavior in members of the group after this new way of conducting the group?

The records of the intervention and the data that emerged from the group interviews were subjected to thematic content analysis $^{(19)}$, more specifically, the procedure per milha. In this type of analysis, the categories are not given a priority, but emerge from analogue classification of elements from the $\mathrm{da}-$ ta analysis. For this analysis, the steps of pre-analysis, material exploration and treatment of results and interpretation ${ }^{(19)}$ were fulfilled. From this process, categories were prepared and named only at the end of the operation. The reported testimonies were identified according to the type of activity that originated the data: intervention group (IG), evaluation interview by the researcher (ER) and evaluation interview by external evaluator (EE), followed by Arabic numerals in chronological order of events (for example, IG).

In conducting the research, ethical principles were followed. The project that initiated the research was approved by the Ethics Committee on Human Research of the Federal University of Triangulo Mineiro, under the Protocol no 1477.

\section{RESULTS}

Participants were 21 seniors, 8 community health agents (CHA) and the nursing technician responsible for coordinating the group. The age of the older adult members ranged from 60 to 83 years, with 18 (85.7\%) female, 
$11(52.4 \%)$ of whom lived with her husband or partner, 6 (28.6\% ) were widowed; 9 (42.9\%) had one to three years of study; 5 (23.8\%) had never studied, 10 (47.6\%) received a minimum wage and 17 (81\%) were housewives.

For members of the health team, considered as the coordinator of the group and the $8 \mathrm{CHA}$, they were aged between $24-51$ years, 4 (44\%) were single and 4 (44\%) had stable partners. As for the occupation time, the coordinator had 22 years of experience and the longest time was 11 years from the CHA. As for education, 6 (66.7\%) had high school.
The analysis of the data content corresponds to the process of change that went through the group and is organized into three categories which reflect the basic movements of the group towards the incorporating the new mode of group operation. The findings were then organized into charts that explain the statements related to each stage, the interpretation and the approach of the researcher, namely: Initial phase - impact of change (Chart 1); Intermediate phase - incorporating the change (Chart 2) and Final phase - changes observed by group members and health professionals (Charts 3 and 4).

Chart 1 - Analysis of the initial phase of the group of senior citizens and the approach of the researcher - Uberaba, MG, 2012.

\begin{tabular}{|c|c|c|}
\hline \multicolumn{3}{|c|}{ Initial phase - impact of change } \\
\hline Testimony & Meaning & Approach \\
\hline Oh come on! You made this up? (IG 1) & \multirow{5}{*}{$\begin{array}{l}\text { Resistance to accept } \\
\text { the new proposal }\end{array}$} & Researcher calls for everyone to participate and recalls the \\
\hline Do we have to speak? (IG 1) & & \\
\hline Uh, I can't draw! (IG 3) & & $\begin{array}{l}\text { Explains that there is no right or wrong, they are not re- } \\
\text { quired to participate, but the participation of all is impor- } \\
\text { tant. }\end{array}$ \\
\hline \multirow[t]{2}{*}{ I can't handle it! (IG 8) } & & $\begin{array}{l}\text { It also recalls the importance of confidentiality and to re- } \\
\text { spect the opinions of others. }\end{array}$ \\
\hline & & Helps those who have difficulty in performing the activity. \\
\hline I'm not doing that. (IG 3) & \multirow{4}{*}{$\begin{array}{l}\text { Being directly op- } \\
\text { posed. }\end{array}$} & \multirow{4}{*}{$\begin{array}{l}\text { Researcher encourages the participation of all, stressing that } \\
\text { there is no right or wrong; that they are not required to par- } \\
\text { ticipate, but the participation of all is important. }\end{array}$} \\
\hline Writing? I'm not writing anything! (IG 4) & & \\
\hline Uh, I'm not gonna get involved with this! (IG 4) & & \\
\hline If I knew it I'd have stayed home! (IG 8) & & \\
\hline Aren't we having Bingo today? (IG 2) & \multirow{2}{*}{$\begin{array}{l}\text { Wanting to keep the } \\
\text { routine }\end{array}$} & \multirow{2}{*}{$\begin{array}{l}\text { Researcher clarifies that bingo activities and forró will be } \\
\text { maintained and that the cooperation agreement at the end } \\
\text { of the meeting time was established and that it would be } \\
\text { respected. }\end{array}$} \\
\hline The Bingo! Where's the Bingo? (IG 4) & & \\
\hline
\end{tabular}

Chart 2 - Analysis of the intermediate phase of the older adults and approach of the researcher - Uberaba, MG, 2012.

\begin{tabular}{|c|c|c|}
\hline \multicolumn{3}{|c|}{ Intermediate phase - incorporating the change } \\
\hline Testimony & Meaning & Approach \\
\hline $\begin{array}{c}\text { I'm excited for Thursdays so I can come here and } \\
\text { meet you! (IG 2) }\end{array}$ & \multirow{7}{*}{$\begin{array}{l}\text { Believing in the new } \\
\text { proposal and feeling } \\
\text { good about it. }\end{array}$} & \multirow{7}{*}{$\begin{array}{l}\text { Researcher encourages the participation of all and calls to } \\
\text { invite others to join the group and also introduces the needs } \\
\text { for the next meetings. }\end{array}$} \\
\hline $\begin{array}{l}\text { I'm fine, too! Thank God! I'm happy to be here with } \\
\text { you (IG 15) }\end{array}$ & & \\
\hline $\begin{array}{l}\text { I miss it when I don't come. It feels like something is } \\
\text { missing, something I forgot to do. (ER 1) }\end{array}$ & & \\
\hline The activities, the games we do on paper, I like it! (ER 2) & & \\
\hline $\begin{array}{l}\text { Now I'm crazy to come. Today I look for people to } \\
\text { know if they'll go. Now I want to sit by other people } \\
\text { to talk to them. I think it's good! (ER 3) }\end{array}$ & & \\
\hline $\begin{array}{l}\text { I could go to the group near my house, but I } \\
\text { come here because I like you guys. It's a long way } \\
\text { but it's worth it! The group is a fraternity.(EE 1) }\end{array}$ & & \\
\hline Now the Bingo and the Gymnastics have to happen (ER 4) & & \\
\hline Now we learn it and do it at home. (IG 3) & \multirow{3}{*}{$\begin{array}{l}\text { Building new knowl- } \\
\text { edge }\end{array}$} & \multirow{3}{*}{$\begin{array}{c}\text { Researcher takes matters previously worked on with the aim } \\
\text { of encouraging constant practice. }\end{array}$} \\
\hline $\begin{array}{l}\text { I did this (shows movement) like she told me to and } \\
\text { it helped my back a lot. (IG 4) }\end{array}$ & & \\
\hline I'm learning things that I've never learned before (EE 2) & & \\
\hline $\begin{array}{l}\text { Today I'm not so good. Problems at home get us } \\
\text { down. At my age and I still have to deal with it. (IG 16) }\end{array}$ & $\begin{array}{l}\text { Sharing sorrows and } \\
\text { joys }\end{array}$ & $\begin{array}{c}\text { Researcher stresses that the group is a place to receive and } \\
\text { offer support. }\end{array}$ \\
\hline $\begin{array}{l}\text { Everybody has problems, right? But if we don't have } \\
\text { support, somebody to vent to, what would happen? } \\
\text { So today if I stand here strong I owe it to the support } \\
\text { I have, my friends and people from this group. (ER 5) }\end{array}$ & & \\
\hline
\end{tabular}




\begin{tabular}{|c|c|c|}
\hline \multicolumn{2}{|c|}{ Intermediate phase - incorporating the change } \\
\hline Testimony & Meaning & Approach \\
\hline $\begin{array}{c}\text { We lost a friend, but we have Mrs. Adalgisa that } \\
\text { needs our support (IG 14) }\end{array}$ & $\begin{array}{c}\text { Sharing sorrows and } \\
\text { joys }\end{array}$ & $\begin{array}{c}\text { Researcher stresses that the group is a place to receive and } \\
\text { offer support. }\end{array}$ \\
\hline $\begin{array}{c}\text { I'm happy because I'm going to meet my daughter } \\
\text { who I haven't seen in } 5 \text { years (IG 12) }\end{array}$ & \\
\hline
\end{tabular}

Chart 3 - Analysis of the final phase of the older adult group and approach of the researcher - Uberaba, MG, 2012.

\begin{tabular}{|c|c|c|}
\hline \multicolumn{3}{|c|}{ Final phase - changes observed by group members } \\
\hline Testimony & Meaning & Approach \\
\hline $\begin{array}{c}\text { I'm a little shy, you know?! Since I've been meeting } \\
\text { with people here I'm getting better, bit by bit. Be- } \\
\text { cause before I was going to dance but felt shy. I can } \\
\text { dance but I don't because I'm shy and here I dance. } \\
\text { I dance!(ER 1) }\end{array}$ & \multirow[t]{3}{*}{ Changing attitudes } & \multirow[t]{3}{*}{$\begin{array}{l}\text { Researcher uses relaxation techniques and others that } \\
\text { stimulate the body language and physical contact in order } \\
\text { to continue the process of personal change. }\end{array}$} \\
\hline $\begin{array}{l}\text { I was more nervous. Now I'm part of the group and } \\
\text { I'm better. (EE } 1 \text { ) }\end{array}$ & & \\
\hline $\begin{array}{l}\text { I'm a new woman. It changed my life! Everything is } \\
\text { better for me thank God! Everything is better (EE 2) }\end{array}$ & & \\
\hline $\begin{array}{l}\text { My health is OK, I'm really excited! I even decided } \\
\text { to study again, because of you. Because it's exciting. } \\
\text { I learn a lot here and I want to learn more! (IG 12) }\end{array}$ & \multirow[t]{2}{*}{ Building knowledge } & \multirow[t]{3}{*}{$\begin{array}{l}\text { Researcher congratulates participant for the initiative and } \\
\text { reinforces the importance of making personal projects. }\end{array}$} \\
\hline We're going to create a group like this in São Basílio & & \\
\hline $\begin{array}{c}\text { We can create an Elderly Association, that way we } \\
\text { can have funds to hire Mrs. Helena for the Gymnas- } \\
\text { tics! (IG 18) }\end{array}$ & Conquering spaces & \\
\hline $\begin{array}{l}\text { I think it's good because we get to know ourselves a } \\
\text { bit more (IG 13) }\end{array}$ & \multirow[t]{3}{*}{ Bonding } & \multirow{3}{*}{$\begin{array}{l}\text { Researcher uses techniques that stimulate the exposure of } \\
\text { ideas, desires, feelings and opinions in order to provide } \\
\text { closer contact between the participants. }\end{array}$} \\
\hline $\begin{array}{l}\text { Neusa came to my house to help me today. She got } \\
\text { me out of bed, organized the house. If it wasn't for } \\
\text { her help I wouldn't have been able to come today. } \\
\text { (IG 10) }\end{array}$ & & \\
\hline $\begin{array}{c}\text { You brought Helena here and now she's part of our } \\
\text { group. (ER 3) }\end{array}$ & & \\
\hline $\begin{array}{c}\text { Before I didn't stretch at home, now I do, after I saw } \\
\text { it here. When I feel pain in my arms or legs I do it, } \\
\text { and it's good. (ER 4) }\end{array}$ & \multirow[t]{4}{*}{$\begin{array}{l}\text { Acquiring new } \\
\text { healthy habits }\end{array}$} & \multirow[t]{4}{*}{$\begin{array}{l}\text { Researcher reinforces the importance of putting into prac- } \\
\text { tice what they have learned in the group. }\end{array}$} \\
\hline I do 'do-in' massages when I have headaches (ER 5) & & \\
\hline $\begin{array}{c}\text { My blood pressure isn't high, but I avoid eating } \\
\text { salty things so I won't have this problem. After I've } \\
\text { learned here to put less salt on food I've been doing } \\
\text { that. (EE 2) }\end{array}$ & & \\
\hline $\begin{array}{l}\text { I taught my daughter to do the 'do-in' massages be- } \\
\text { cause she has fibromyalgia (ER 6) }\end{array}$ & & \\
\hline
\end{tabular}

Chart 4 - Analysis of the final phase of the older adult group from the perspective of health professionals and the approach of the researcher - Uberaba, MG, 2012.

\begin{tabular}{|c|c|c|}
\hline \multicolumn{3}{|c|}{ Final phase - changes observed by health professionals } \\
\hline Testimony & Meaning & Approach \\
\hline $\begin{array}{c}\text { Their participation is more alive. Because when it was } \\
\text { only me they already knew what to expect every week, } \\
\text { every meeting. Sometimes we're able to do something } \\
\text { new. Now, knowing that you're going they are already } \\
\text { expecting more. (ER 1) }\end{array}$ & $\begin{array}{l}\text { Bringing news/ pre- } \\
\text { senting new ways of } \\
\text { managing and con- } \\
\text { ducting the group }\end{array}$ & $\begin{array}{l}\text { Researcher involves professionals in planning and car- } \\
\text { rying out activities and emphasizes that even at the end } \\
\text { of the research they will assist in the coordination of } \\
\text { group activities. }\end{array}$ \\
\hline $\begin{array}{l}\text { It's gotten much, much better. The group opens up } \\
\text { more, they participate more and they get more excited, } \\
\text { more opinionative (ER } 2 \text { ) }\end{array}$ & \multirow[t]{2}{*}{$\begin{array}{l}\text { Encouraging the } \\
\text { participation of } \\
\text { members }\end{array}$} & \multirow{2}{*}{$\begin{array}{l}\text { Researcher encourages participation of all (members } \\
\text { and health professionals) and again requests that others } \\
\text { are invited to join the group and encourage them to } \\
\text { make suggestions of techniques for use in future meet- } \\
\text { ings. }\end{array}$} \\
\hline $\begin{array}{l}\text { I think they're participating more. More people are com- } \\
\text { ing. Because before they'd come but it was less people. } \\
\text { After they started coming to the meetings, more people } \\
\text { are coming. I think it's getting more interesting and } \\
\text { they're bringing other people with them. I believe so. } \\
\text { I think it's better and that they're more engaged (ER 3) }\end{array}$ & & \\
\hline
\end{tabular}




\begin{tabular}{|c|c|c|}
\hline \multicolumn{3}{|c|}{ Final phase - changes observed by health professionals } \\
\hline Testimony & Meaning & Approach \\
\hline $\begin{array}{l}\text { It's different. Because I didn't have the step by step } \\
\text { before. You follow the steps, right? You have a plan and } \\
\text { I don't. You got here with methodology that involves } \\
\text { them, gets their attention, and creates an outcome at } \\
\text { the end. Because you see that you've accomplished } \\
\text { something at the end. So it's gotten better with that. (ER } \\
4 \text { ) }\end{array}$ & $\begin{array}{l}\text { Recognizing the } \\
\text { new, thinking about } \\
\text { changes }\end{array}$ & $\begin{array}{l}\text { Researcher points out that professionals involved with } \\
\text { the coordination have the conditions to continue the } \\
\text { new way of guiding and group management, and em- } \\
\text { phasizes again that even at the end of the research they } \\
\text { will assist in the coordination of group activities. }\end{array}$ \\
\hline $\begin{array}{c}\text { It was very good. It's good because I'm learning. Be- } \\
\text { cause my way of doing things is completely different } \\
\text { from yours. You go slowly while I'm more direct. So I'm } \\
\text { learning that sometimes we have to go slower, right? } \\
\text { (ER 5) }\end{array}$ & \multirow[t]{2}{*}{$\begin{array}{l}\text { Learning from the } \\
\text { new }\end{array}$} & \multirow[t]{2}{*}{$\begin{array}{l}\text { Researcher stresses that health professionals are able to } \\
\text { continue the new way to lead the group and that they } \\
\text { are able to improve what already exists. }\end{array}$} \\
\hline $\begin{array}{l}\text { I thought that day of the Bingo, when you asked to } \\
\text { bring fruit, was very important. That day, for example, } \\
\text { somebody got a banana, an okra, a berry. And you ex- } \\
\text { plained what each fruit is good for, and so on. I thought } \\
\text { it was very significant and we could always have that. } \\
\text { (EE) }\end{array}$ & & \\
\hline $\begin{array}{l}\text { They learn more... I think it's being together, being to- } \\
\text { gether and relating with others. I think that's the biggest } \\
\text { lesson for them.(ER 6) }\end{array}$ & $\begin{array}{l}\text { Learning to live and } \\
\text { relate to others }\end{array}$ & $\begin{array}{l}\text { Researcher stresses the importance of keeping tech- } \\
\text { niques that encourage self-awareness and interpersonal } \\
\text { relationships. }\end{array}$ \\
\hline
\end{tabular}

\section{DISCUSSION}

The proposed change in the group's operating dynamics caused a common movement of human groups when starting or when there is new coordination ${ }^{(18,20)}$. Analyzing the group process in the initial phase (Chart 1), it was observed that the change in the functioning of the group in the early meetings caused some discomfort for some elderly who were uncomfortable, indicating some resistance to participate in the proposed activities. Others showed apprehensiveness about the end time of the activity, looking at their watch frequently or claiming to have commitments. Some showed dissatisfaction for the delay in starting the bingo.

These behaviors expressed that the resistance ${ }^{(18)}$ to adhere to the activities was due to the different pace adopted in conducting the group and also the difficulty of leaving their comfort zone, given that there was already an established routine. The change of indication on how the group functions can in principle pose a threat to members that accommodated the known situations, they fear the new ${ }^{(18.21)}$. When you want to introduce an innovative proposal, the advantages of investing in change have to be shown gradually to the group ${ }^{(21)}$.

Sometimes the older people were more distracted, and other times less participant. Some remained quiet, especially when asked questions. Thus, they showed themselves to be afraid or inhibited in expressing thoughts/feelings. The fear in expressing their opinions may have occurred because of new techniques that were being inserted and not necessarily indicative of disinterest. Such actions characterize the initial phase of human groups that fearing the new can inhibit or cause defensiveness ${ }^{(18.21}$ to 22$)$.

When registering any change in their usual way of working, defense mechanisms become the insurance process in order to avoid changes or to defend against anxiety. Such behavior is observed in resistance to changing the room or a mobile environment to the non-acceptance of a reflection or a suggestion for the use of a technique by the trainer, as shown in Chart 1 - testimonies IG $4 \mathrm{a}$ and IG $4 \mathrm{~b}$. On the other hand, you must accept the individuality and tolerate individual differences, subject to the time for each member to process their learning ${ }^{(20-21)}$.

As the meetings were going on, the group was more receptive and engaged, actively participating in the proposed activities (Chart 2). The ideas were welcomed and all participated with more satisfaction, without worrying about the time. Unlike at the beginning of the group, it was realized that the members began to feel more comfortable, expressing greater autonomy and participation. The actions presented in the intermediate phase (Chart 2) express the time the group became closer and was more confident in themselves and their coordination ${ }^{(20-21)}$.

The group has also become an area used to vent sorrows/ stress and share happiness/fun. It represented a welcoming environment where troubles were verbalized and shared. In this phase, the loss of one of the members from passing away mobilized the group to welcome the wife who was also part of the group (Chart 2 - IG testimony 14). On several occasions, some took the initiative to bring messages for group reflection. This expresses effective participation and interest in collaborating with the other members because of the choice and reading of the text revealed a way to contribute to the group. On the other hand, it reflects the acceptance, support and the incorporation of the new proposal by the researcher. Therefore, it is important to note that the support of the group or its members reflects the need to help each other, meaning the pursuit of integration and group cohesion. This support comes from the need to create a sense of belonging to something ${ }^{(20)}$. A study conducted in adults and elderly in a day center observed higher positive affect levels in activities that included creativity or group process ${ }^{(23)}$.

An interesting characteristic of this group was how they welcomed new participants, whether they were young, children or strangers from another location, an aspect pointed out in ER testimony 3 in Chart 3. From the beginning, it was observed that the group members did not put up any resis- 
tance to welcoming new members. On the contrary, they allowed the newcomer to feel integrated quickly. This behavior differs from what is theoretically defined as a reaction to a foreigner ${ }^{(20)}$, a common movement of tension in human groups when a new element is inserted into an already established group $^{(18)}$ and some behaviors and attitudes of anxiety, tension and questions by the other members can be observed ${ }^{(18)}$, and expectation, shyness and anxiety by the foreigner.

Another peculiarity of the group was observed in joint activities within the group environment and outside of it. Participants extended several activities beyond the group space, with reports of one helping the other, whether in their household or in providing emotional support (Chart 3 - IG testimony 10).

At this stage of life, strategies should be developed to minimize the level of loneliness, such as evaluation services and psychological and physical treatment, which can also increase the opportunity of participation in group $\operatorname{activities}^{(24)}$.

At each meeting the desire of the members to participate in the group became more noticeable (Chart 2 - testimonials ER 1, ER 2 and ER 3). It was felt that there was a commitment not only to the researcher, but also to the other participants. As an example, there was an 83-year-old man as one of the members who moved to a neighborhood located in the urban area and despite the distance and difficulties related to his routine to take the bus and the commute time, he continued participating in the group activities. Even having the opportunity to participate in other groups closer to his home, he opted to stay with us. It is a commitment to continue participating that expresses the importance of the group in your life, as described by the testimony EE 1, Chart 2.

It is still possible to see the evolution of the group in relation to the expression of ideas, opinions, emotions and feelings, which is shown by the interaction, trust and confidence between the group members. At a meeting, a guest showed the practice of stretching and was promptly included by the group and invited to attend their activities. Thus, the stretching, as well as bingo, was incorporated as routine activities in the group meetings (Chart 2 - ER testimony 4).

The group also revealed space to increase their healthrelated knowledge, which provided behavioral changes; among which are cited acquisition of new health-related habits, change in interpersonal and social relationships, improved self-esteem and relief from various symptoms, as observed in the statements ER 4, ER 5 and EE 3 described in Chart 3, and these results were also found in other studies $^{(25-26)}$. International research suggests that programs targeted to seniors can contribute to the improvement of their physical and functional capacity, physical activity and energy, improving their quality of life ${ }^{(27)}$.

Also noteworthy is the fact that the group members act as multipliers of learning, considering that they replicated what they learned in other environments (Chart 3 - ER testimony 6). In this sense, the group activity enables learning by providing an exchange of information and experiences ${ }^{(26-28)}$.
The participation of members, the enjoyment and interest in activities went up. The local coordinator who had been integrated into the new form of management of the group was very active, actively participating in both the planning and execution of activities. The coordinator showed interest in learning about group management techniques and constantly expressed enjoyment and satisfaction of the collaboration with their development and professional growth and also with the group's progress, as described in Chart 4 - testimonials ER 3, ER 4 and ER 5.

Six months after the start of the intervention, meaning the change in the proposal of the group's functioning, there were some features not previously presented. Its members showed more determination with regard to decision-making, as well as expressing opinions, a fact confirmed by the local coordinator (Chart 4 - ER testimony 2). This reflects the autonomy achieved through social participation, as the group activity provided adequate space for the development of citizenship. In this sense, the priority is the development of programs to promote personal autonomy among the elderly, aimed at physical, mental, emotional and social well-being ${ }^{(29)}$.

The evaluation of the intervention carried out by the group members and by health professionals is noteworthy as their testimony showed that the work was positive, contributing to the growth and development of the group as well as for training the professionals involved. It also is worth noting that the good results achieved prompted an initiative to form another group in a nearby community, also for older people; members also expressed their intention to create an Elderly association (testimony ER 2 and IG 18 of Chart 3, respectively). In this context, it is noted that accessibility is a strong factor influencing participation of older people in social groups ${ }^{(30)}$, a relevant aspect especially in rural areas where distance may discourage participation in activities. Thus, the initiative to create new sites can facilitate access for enabling the group.

\section{CONCLUSION}

This research described the process of empowerment phases of a group in a rural community which led to positive changes, both for members and for the professionals who were trained during the research for conducting the group in order to use its therapeutic potential.

Incorporating healthy habits (such as stretching, practicing do-in and healthy eating), the improvement in interpersonal relationships and the management methodology by health professionals showed that the CCR in this sense was a strategy that empowered the action of the group members and professionals. Changes in health habits were consolidated by group members who have become multipliers of this knowledge within their community.

Despite the initial impact of the change in the way the group was conducted (to which there was initially resistance), the group was able to welcome the new changes, taking advantage of the space to express anxieties, share happiness and learn new knowledge.

For health professionals, the intervention was an opportunity for reflection and professional growth, as well as 
a time to rethink the group's conduct methodology. Once empowered with new knowledge and skills, professionals gained greater autonomy and capacity for innovation.

The research results allow us to state that training professionals responsible for group activities being aimed at rural communities is an assertive strategy to enhance the therapeutic effects of group living for the elderly in this scenario.

As a limitation in the study, there was a lack of involvement of the FHS professionals in group activities. Consid- ering the findings of the investigation, we point to a knowledge gap in the need for investment in studies assessing the impact of group activities aimed at elderly populations, particularly in rural communities.

Such studies may give clues as to how best conduct such activities for strengthening the autonomy, stimulating self-care, as well as for the development of personal skills, all fundamental aspects when seeking health promotion in old age.

\section{RESUMO}

Objetivo: Descrever as fases do processo de potencialização de um grupo de terceira idade de uma comunidade rural. Método: Pesquisa convergente assistencial cujo fundamento é utilizar o espaço da prática. Conduzida com a proposta de mudar a práxis de 21 idosos e nove profissionais de saúde, com vistas a sua potencialização para a promoção da saúde. Os dados foram coletados durante 22 encontros, além de entrevistas grupais ao final da intervenção. Resultados: Mostraram que apesar do impacto inicial da mudança, o grupo foi capaz de acolher a novidade, aproveitando o espaço para expressar angústias, compartilhar alegrias, construir novos conhecimentos, o que levou à incorporação de mudanças que refletiram na elaboração de hábitos saudáveis e melhora no relacionamento interpessoal. Conclusão: A pesquisa convergente assistencial se constituiu em estratégia que modificou a vida grupal, potencializando as ações de promoção da saúde.

\section{DESCRITORES:}

Idoso; População Rural; Processos Grupais; Promoção da Saúde; Enfermagem em Saúde Comunitária; Saúde do Idoso.

\section{RESUMEN}

El presente estudio describe las etapas de la capacitación de un grupo de personas mayores en una comunidad rural en la vista del análisis convergente. Estudio realizado con la propuesta de cambiar la praxis de 21 personas mayores y nueve profesionales de la salud, con miras a su capacitación para la promoción de la salud, cuya intervención se sugiere la incorporación de nuevo el funcionamiento del grupo. Los datos fueron recolectados durante 22 reuniones y entrevistas de grupos al final de la intervención. Los resultados muestran que a pesar del impacto inicial de la modificación, el grupo fue capaz de dar la bienvenida al nuevo, disfrutando del espacio para expresar la angustia, compartir alegrías, construir nuevos conocimientos, lo que llevó a la incorporación de los cambios se reflejan en el desarrollo de hábitos saludables y de mejora en las relaciones interpersonales. Se concluye que la investigación convergente consistió en la estrategia que cambió la vida de grupo, potenciando las acciones de promoción de la salud.

\section{DESCRIPTORES:}

Anciano; Población Rural; Procesos de Grupo; Promoción de la Salud; Enfermería en Salud Comunitária; Salud del Anciano.

\section{REFERENCES}

1. Instituto Brasileiro de Geografia e Estatística (IBGE). Censo demográfico 2010: características da população e dos domicílios: resultados do universo [Internet]. Rio de Janeiro: IBGE; 2011 [citado 2014 fev. 26]. Disponível em: http://www.ibge.gov.br/english/estatistica/populacao/ censo2010/caracteristicas_da_populacao/resultados_do_universo.pdf

2. Nogueira ALG, Munari DB, Santos LF, Oliveira LMAC, Fortuna CM. Therapeutic factors in a group of health promotion for the elderly. Rev Esc Enferm USP. 2013; 47(6):1352-8.

3. Silva JRG, Galdino MNAS, Bezerra ALD, Sousa MNA. Direito à saúde: revisão integrativa da literatura sobre o acesso de idosos aos serviços de saúde. Rev Eletr Fainor [Internet]. 2012 [citado 2013 set. 21];5(1):25-42. Disponível em: http://srv02.fainor.com.br/revista/index.php/ memorias/article/view/145

4. Carvalho SR, Gastaldo D. Promoção à saúde e empoderamento: uma reflexão a partir das perspectivas crítico-social pós-estruturalista. Ciênc Saúde Coletiva [Internet]. 2008 [citado 2013 set. 21];13Supl. 2:2029-40. Disponível em: http://www.scielo.br/pdf/csc/v13s2/ v13s2a07.pdf

5. Magnabosco P, Nogueira MS. Avaliação da contribuição do grupo de convivência para o cuidado do indivíduo Rev Eletr Enferm [Internet]. 2011 [citado 2013 set. 21];13(1):110-7. Disponível em: http://dx.doi.org/10.5216/ree.v13i1.11437

6. Van Leuven KA. Health practices of older adults in good health. J Gerontol Nurs 2010;36(6):38-46.

7. Dias FA, Tavares DMS. Fatores associados à participação de idosos em atividades educativas grupais. Rev Gaúcha Enferm. 2013;34(2):70-77.

8. Tahan J, Carvalho ACD. Reflexões de idosos participantes de grupos de promoção de saúde acerca do envelhecimento e da qualidade de vida. Saúde Soc [Internet]. 2010 [citado 2013 set. 21];19(4):878-88. Disponível em: http://www.revistas.usp.br/sausoc/article/ view/29710/31585

9. Machado VB, Barros APM. Revisão sistemática sobre os benefícios adquiridos na promoção do envelhecimento saudável. Gestão Saúde [Internet]. 2012 [citado 2013 set. 21];3(2):692-703. Disponível em: http://gestaoesaude.unb.br/index.php/gestaoesaude/article/view/181 
10. Almeida SP, Soares SM. Aprendizagem em grupo operativo de diabetes: uma abordagem etnográfica. Ciênc Saúde Coletiva. $2010 ; 15$ Supl. 1:1123-32.

11. Combinato DS, Dalla Vecchia M, Lopes EG, Manoel RAM, Oliveira ACS, Silva KF. "Grupos de conversa": saúde da pessoa idosa na Estratégia Saúde da Família. Psicol Soc. 2010;22(3):558-68.

12. Bertuzzi D, Paskulin LGM, Morais EP. Arranjos e rede de apoio familiar de idosos que vivem em uma área rural. Texto Contexto Enferm. 2012;21(1):158-66.

13. Santos EA, Tavares DMS, Rodrigues LR, Dias FA, Ferreira PCS. Morbidity and quality of life of elderly individuals with diabetes mellitus living in urban and rural areas. Rev Esc Enferm USP. 2013;47(2):393-400.

14. Tavares DMS, Arduini AB, Dias FA, Ferreira PCS, Oliveira EA. Perfil sociodemográfico, capacidade funcional e qualidade de vida de homens idosos residentes na zona rural. Rev REAS [Internet]. 2012 [citado 2013 set. 21];1(1):16-29. Disponível em: http://www.uftm.edu.br/revis

15. Tavares DMS, Gomes NC, Dias FA, Santos NMF. Fatores associados à qualidade de vida de idosos com osteoporose residentes na zona rural. Esc Anna Nery. 2012;16(2):371-8.

16. Trentini M, Paim L. Pesquisa convergente assistencial. Florianópolis: Insular; 2004.

17. Paim L, Trentini M, Madureira VSF, Stamm M. Pesquisa convergente assistencial e sua aplicação em cenários da Enfermagem. Cogitare Enferm. 2008;13(3):380-6.

18. Lewin K. Dinâmica de grupo. São Paulo: Cultrix; 1948.

19. Bardin L. Análise de conteúdo. Lisboa: Editora 70; 2011.

20. Castilho A. Dinâmica do trabalho de grupo. $2^{\text {a }}$ ed. Rio de Janeiro: Qualitymark; 1998.

21. Mota KAMB, Munari DB. Um olhar para a dinâmica do coordenador de grupos. Rev Eletr Enferm [Internet]. 2006 [citado 2013 set. 21];8(1):150-61. Disponível em: http://www.fen.ufg.br/revista/revista8_1/atualizacao.htm

22. Munari DB, Padilha GC, Motta KAMB, Medeiros M. Contribuições para a abordagem da dimensão psicológica dos grupos. Rev Enferm UERJ. 2007;15(1):107-12.

23. Rowe JM, Savundranayagam MY, Lang J, Montgomery RJV. Characteristics of creative expression activities: the links between creativity, failure-free, and group process with levels of staff-participant engagement and participant affect in an adult day center. Act Adapt Aging. $2011 ; 35(4): 315-30$

24. Wu ZQ, Sun L, Sun YH, Zhang XJ, Tao FB, Cui GH. Correlation between loneliness and social relationship among empty nest elderly in Anhui rural area, China. Aging Mental Health. 2010;14(1):108-12.

25. Bernardo MHJ, Menezes MFG, Assis M, Pacheco LC, Mecenas AS. A saúde no diálogo com a vida cotidiana: a experiência do trabalho educativo com idosos no grupo da roda da saúde. Rev APS. 2009;12(4):504-9.

26. Camargo AM, Silva APBV, Wolff LDG, Soares VMN, Gonçalves CGO. Abordagens grupais em saúde coletiva: a visão de usuários e de profissionais de enfermagem. Rev Bras Ciênc Saúde [Internet]. 2012 [citado 2014 out. 16];10(31). Disponível em: http://seer.uscs.edu.br/ index.php/revista_ciencias_saude/article/view/1475

27. Oztürk A, Simşek TT, Yümin ET, Sertel M, Yümin M. The relationship between physical, functional capacity and quality of life (QoL) among elderly people with a chronic disease. Arch Gerontol Geriatr. 2011;53(3):278-83.

28. Maffacciolli R, Lopes MJM. Os grupos na atenção básica de saúde de Porto Alegre: usos e modos de intervenção terapêutica. Ciênc Saúde Coletiva. 2011;16 Supl.1: 973-82.

29. Herrera Molina E, Muñoz Mayorga I, Martin Gálan V, Cid Gala M. Experiencias españolas en la promoción de la autonomía personal en las personas mayores. Gac Sanit. 2011;25 Suppl 2:147-57.

30. Tanaka M, Ushijima K, Sung W, Kawakita M, Tanaka S, Mukai Y, et al. Association between social group participation and perceived health among elderly inhabitants of a previously methylmercury-polluted area. Environ Health Prev Med. 2014;19(4):258-64. 